\title{
AN EXPERIMENTAL STUDY ON SHRINKAGE BEHAVIOUR OF EARTH BRICKS REINFORCED WITH STRAW
}

\author{
Ashour, T.*
}

ABSTRACT

There is a growing interest in using earth as a building material which exhibits excellent physical properties with respect to ecological design, and fulfils all strength and serviceability requirements for thermal transmittance. In this paper a series of laboratory tests on shrinkage of earth bricks materials is presented. The brick materials consist of cohesive soil, cement, gypsum and different natural fibres. Two types of fibres, wheat and barley straw were used as reinforcement in the tests. Cement and gypsum was used as stabilized materials. The shrinkage behavior of bricks was studied by laboratory tests for different compositions. The specimens of brick material were dried under a constant temperature of $105^{\circ} \mathrm{C}$ respectively. The average shrinkage percentage of unfired earth bricks reinforced with wheat straw are 4.161, 2.615 and $0.573 \%$ for the fibres contents of $0 \%, 1 \%$ and $3 \%$ respectively, while the shrinkage percentages for bricks reinforced with barley straw fibres are 4.161, 3.458 and $0.613 \%$ for reinforcement fibres contents of $0 \%, 1 \%$ and $3 \%$ respectively. The percentages of shrinkage for bricks reinforced with barley straw fibres are 3.458, 3.51and 3.60\% for cement contents of $0 \%, 5 \%$ and $10 \%$ respectively. additionally, the percentages of shrinkage for bricks reinforced with barley straw fibres are 3.458, 3.677 and $3.829 \%$ for gypsum contents of $0 \%, 5 \%$ and $10 \%$ respectively. The results revealed that fibres content have greater effect on shrinkage behaviour than gypsum and cement content.

Key Words: earth bricks, shrinkage, soil, straw, cement, gypsum.

\footnotetext{
* Associate Prof. of Agric. Eng. Dept., Fac. Agric. Moshtohor, Toukh, Qalubia, P.O. Box 13736, Benha University, Egypt.

E-mail:taha.ashour@fagr.bu.edu.eg
} 


\section{INTRODUCTION}

sustainability building is one in which technology and practice
meets the multiple requirements of the people and society in an
optimal way during the life cycle of the building facility (AIA, 2006). There is a growing interest in using earth as a building material which exhibits excellent physical properties with respect to ecological design, and fulfils all strength and serviceability requirements for thermal transmittance. This development is also due to the present concerns for sustainable development that have arisen out of extensive environmental problems (such as climate change and impoverishment of resources) and also rapid pace of technological development within the building sector (Ashour et al., 2010, Ashour et al., 2011). Straw is a natural product, grown by photosynthesis during a half or one-year period, fueled by the sun. Straw is currently produced in surplus to requirements, so it is cheap and easily accessible in most countries. It is the end product of growing crops; so using it for building purposes present a sustainable and ecological way of recycling (Ashour et al., 2011). The use of natural fibres as reinforcing agents in composite materials offers many advantages such as low density and biodegradability (Li et al., 2006, Mwaikambo and Ansell 2003, Joshi et al., 2004). The natural fibres used in the tests are wheat straw, barley straw and wood shavings. Both the soil composition and the fibre content are varied in the tests. The fibre content and the fibre type are found to have remarkable effect on the erosion resistance of the plasters (Ashour and Wu 2010). The use of natural earth bricks is experiencing a renaissance in sustainable building practice. Earth plasters may serve multiple purposes, e.g. to protection the underlying surface, enhancing or preventing the migration of moisture and carrying structural load. An important issue for the performance of earth plasters is its shrinkage behavior. The excessive formation of drying cracks has negative impact on the durability of earth bricks. Hossain et al. (2007) studied the influence of stabilization of soils by using volcanic ash. drying shrinkage were investigated. He found that better shrinkage resistance of volcanic ash stabilized soil mixtures compared to cement/lime stabilized soils suggests the viability of using such stabilized soils. Bouhicha et al. (2005) investigated a composite soil reinforced with chopped barley straw with four different soils. The effect of fibre 
length and fibre content on shrinkage was studied. Their tests showed the positive effect of straw in decreasing shrinkage-induced cracks. The effect of fibre and earth composition on shrinkage was also investigated by Yetgin et al. (2006). Campbell and Coutts (1980) investigated the possibility of using the wood fibres as reinforcement for a structural composite material. Their results indicated that pulp is suitable for applications where slurry dewatering can be employed during the forming operation and that the thermo mechanical pulp is more suited for applications where low water-cement ratio slurry is used. Bai et al. (2005) measured the drying shrinkage of concrete with natural sand replaced with furnace bottom ash. Their tests showed that at fixed watercement ratio the compressive strength and the drying shrinkage decreased with increasing sand content. Al-Amoudi et al. (2006) compared four types of super plasticizers and used them in conjunction with three types of silica fume to prepare cement concrete slab specimens that were utilized to measure plastic shrinkage strain and time to attain maximum strain. Ashour et al. (2010) mentioned that, the average shrinkage ratios ranged between $0.82-1.03,1.15-1.85$ and $2.60-5.40 \%$ for the curing temperatures of 30,50 and $70{ }^{\circ} \mathrm{C}$, respectively. The highest shrinkage was observed for plaster reinforced with wood shavings, while the lowest shrinkage was observed for plaster reinforced with barley straw fibres. Montes-H. (2005) mentioned that swelling and shrinkage potential is governed by the relative humidity and by the nature of the interlayer cation. The objective of this work is attempt to investigate the drying shrinkage of earth bricks reinforced by different fibres types and contents with different cement and gypsum content.

\subsection{Materials tested}

Earth brick usually comprises four components such as cohesive soil, cement, gypsum and agro fibres. The composition of the cohesive soil texture is as follows: $28.7 \%$ clay, $63.3 \%$ silt, $3 \%$ gravel and $5 \%$ sand. Two different fibre types, wheat and barley straw, were applied for reinforcement. The length of straw particles is about $4 \mathrm{~cm}$.

\subsection{Sample preparation}

At first, oversized gravel and organic matter (grass roots) were removed from the natural cohesive soil. The soil samples were put in an oven to 
dry at a temperature of $105^{\circ} \mathrm{C}$ to obtain the dry constant weight. The natural fibres were also oven dried at $105^{\circ} \mathrm{C}$ to obtain a constant mass. A variety of earth bricks with different compositions of cohesive soil, cement, gypsum and fibre were used in the tests. The dosing of different materials was controlled by the dry weight. The amount of soil, cement, gypsum and fibre of a given mixture were placed in a mechanical mixer and dry blended for circa 30 minutes until the different materials were homogeneously combined. Afterwards, water was sprayed over the mixture until $24 \%$ moisture content level was achieved. The materials were again blended using an electric mixer for approximately 30 minutes until a homogenous mixture was obtained.

Earth bricks from different mixtures combined with different natural fibres that were used in the shrinkage test are given in Table 1.

Table(1): Recipes of earth bricks.

\begin{tabular}{cccccc}
\hline Recipes & $\begin{array}{c}\text { clay } \\
(\boldsymbol{\%})\end{array}$ & $\begin{array}{c}\text { barley } \\
(\boldsymbol{\%})\end{array}$ & $\begin{array}{c}\text { Wheat } \\
(\boldsymbol{\%})\end{array}$ & $\begin{array}{c}\text { cement } \\
(\boldsymbol{\%})\end{array}$ & $\begin{array}{c}\text { Gypsum } \\
(\boldsymbol{\%})\end{array}$ \\
\hline $\mathrm{Clay}$ & 100 & - & - & - & - \\
$\mathrm{B}_{1}$ & 99 & 1 & - & - & - \\
$\mathrm{W}_{1}$ & 99 & - & 1 & - & - \\
$\mathrm{B}_{3}$ & 97 & 3 & - & - & - \\
$\mathrm{W}_{3}$ & 97 & - & 3 & - & - \\
$\mathrm{B}_{1} \mathrm{C}_{5}$ & 94 & 1 & - & 5 & - \\
$\mathrm{W}_{1} \mathrm{C}_{5}$ & 94 & - & 1 & 5 & - \\
$\mathrm{B}_{1} \mathrm{C}_{10}$ & 89 & 1 & - & 10 & - \\
$\mathrm{W}_{1} \mathrm{C}_{10}$ & 89 & - & 1 & 10 & - \\
$\mathrm{B}_{3} \mathrm{C}_{5}$ & 92 & 3 & - & 5 & - \\
$\mathrm{W}_{3} \mathrm{C}_{5}$ & 92 & - & 3 & 5 & - \\
$\mathrm{B}_{3} \mathrm{C}_{10}$ & 87 & 3 & - & 10 & - \\
$\mathrm{W}_{3} \mathrm{C}_{10}$ & 87 & - & 3 & 10 & - \\
$\mathrm{B}_{1} \mathrm{G}_{5}$ & 94 & 1 & - & - & 5 \\
$\mathrm{~W}_{1} \mathrm{G}_{5}$ & 94 & - & 1 & - & 5 \\
$\mathrm{~B}_{1} \mathrm{G}_{10}$ & 89 & 1 & - & - & 10 \\
$\mathrm{~W}_{1} \mathrm{G}_{10}$ & 89 & - & 1 & - & 10 \\
$\mathrm{~B}_{3} \mathrm{G}_{5}$ & 92 & 3 & - & - & 5 \\
$\mathrm{~W}_{3} \mathrm{G}_{5}$ & 92 & - & 3 & - & 5 \\
$\mathrm{~B}_{3} \mathrm{G}_{10}$ & 87 & 3 & - & - & 10 \\
$\mathrm{~W}_{3} \mathrm{G}_{10}$ & 87 & - & 3 & - & 10 \\
\hline
\end{tabular}


The material compositions in Table 1 are given as a percentage of earth material as dry weight. The soil-fibre mixture was then poured into a steel mould and compacted in a press. The inside dimensions of steel mould have a length of $15 \mathrm{~cm}$, by width of $4 \mathrm{~cm}$, and height of $4 \mathrm{~cm}$ (see Fig. 1). The surface was levelled and compressed using a loading plate under a force of about $50 \mathrm{~kg}$. The samples were further dried in an oven under the temperature of $105^{\circ} \mathrm{C}$ to obtain a constant mass, which was controlled by weighing the samples every 24 hours. Thirty samples of different bricks materials were used for shrinkage test.

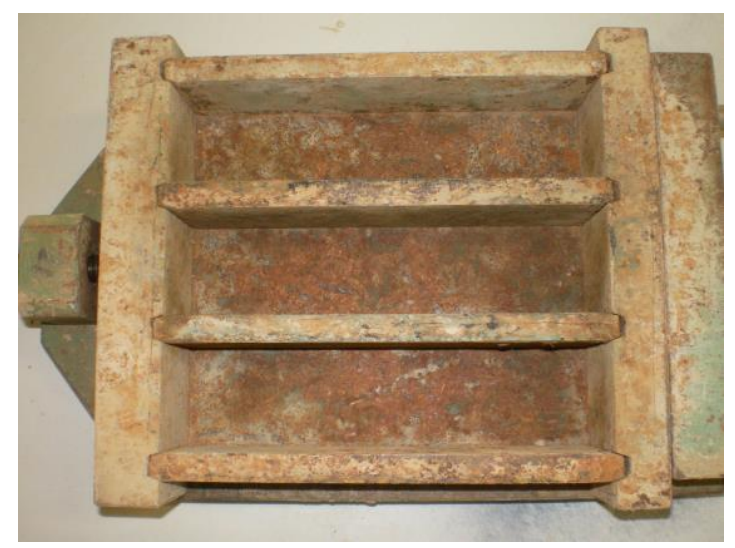

Fig. (1): Frame for sample preparation

\subsection{Scanning electron microscopy}

To test the fibre/matrix adhesion and composite morphology, micrographs in scanning electron microscopy (SEM) were taken. The SEM fracture surface were prepared by using drying bricks . The brick was cutting to appear the inside surface of the bricks and show the fibres distribution. Five replicates were used for each recipe.

\subsection{Shrinkage test procedure}

Shrinkage tests were carried out according to (ASTM D4943, 1995). The soil-fibre mixture was poured into a steel mold. The inside dimensions of steel mold were length of $15 \mathrm{~cm}, 4 \mathrm{~cm}$ in width and $4 \mathrm{~cm}$ in depth (Fig. 1). The materials were poured into the mold and compressed. Afterwards the samples were placed in the oven and dried under constant temperature until the constant weight according to (DIN EN ISO 12570, 2000) was obtained. 


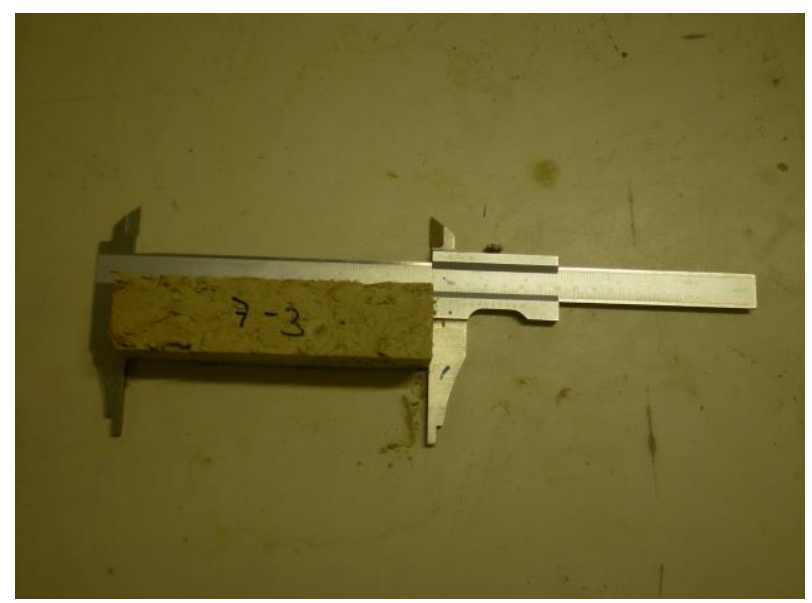

Fig. (2): Vernier scale for measuring the shrinkag The samples dimensions were measured with a vernier scale (Fig. 2).

\section{RESULTS AND DISCUSSIONS}

\subsection{The influence of different components on bricks density}

The effect of fibre content on bricks density was investigated. As expected, the dry density decreased when the fibre quantity increased. It is well demonstrated that, the new blocks manufactured with wheat straw fibre have a relatively high density varying between 1476 and $1277 \mathrm{~kg} / \mathrm{m}^{3}$ for $1 \%$ and $3 \%$ fibre contents respectively. This corresponds to a decrease of about $8.8 \%$ to $21 \%$ in comparison with non-fibrous cohesive soil bricks.

For bricks reinforced with barley straw fibres, it can be seen that the average density ranged between 1445 to $1099 \mathrm{~kg} / \mathrm{m}^{3}$. This means that the density decreased from 10.6 to $33 \%$ when the fibre content increased from $1 \%$ to $3 \%$. It could be noticed that the brick densities reinforced with wheat straw are higher than bricks reinforced with barley straw. This may be due to wheat straw containing more solid material and lignin than barley straw. The average brick densities stabilized with cement are 1310 and $1229 \mathrm{~kg} / \mathrm{m}^{3}$ for $5 \%$ and $10 \%$ cement content at $1 \%$ fibre content. The bricks densities reinforced with barley straw are 1204 and $1112 \mathrm{~kg} / \mathrm{m}^{3}$ at $5 \%$ and $10 \%$ cement contents. The average brick densities stabilized with cement are 1004 and $1040 \mathrm{~kg} / \mathrm{m}^{3}$ for 5 and $10 \%$ cement at $3 \%$ fibres while bricks reinforced with barley straw are 1146 and 1025 $\mathrm{kg} / \mathrm{m}^{3}$ at $5 \%$ and $10 \%$ cement contents at the same fibre content. In 
general, increasing the fibre content in the mixtures decreased the specimen weights. Replacing soil cement or soil gypsum (dense materials) with wheat or barley straw fibres (light materials) resulted in a total volume increase even after compaction. The compacted mix volume increases resulted in a decrease in specimen weights and densities (Duke and Atchly 1984, TS, 1979).

\subsection{Microstructure of earth bricks.}

The morphology and microstructure of the residues were examined by scanning electron microscopy (SEM).The distribution of fibers in the brick are shown in Fig. 3a and b Fig. 3a shows the cross section of fibres distribution. While Fig. 3b illustrate the typical SEM micrographs taken at the top surface of the blocks. It reveal a uniform distribution of fibers inside the brick samples. The micrographs clearly show that the straw fibers were randomly oriented within the samples. Additionally, the moisture equilibrium is mainly influenced by the pore size, with porespecific surface and the percentage of micropores playing a fundamental role in promoting the structure/water interactions.

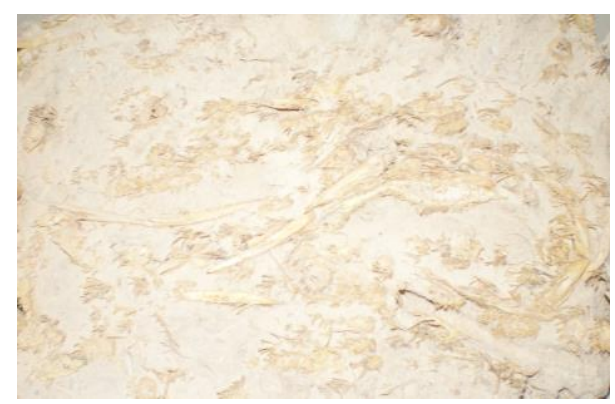

a)

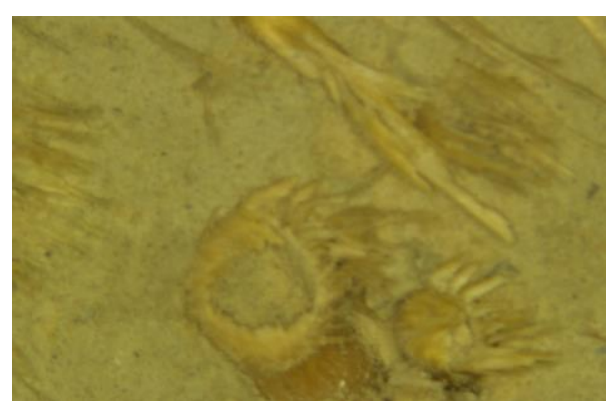

b)

Fig. (3). Fibres distribution inside the bricks, a) cross section showed fibres distribution, b) SEM micrograph of fibres distribution inside the earth bricks.

\subsection{Shrinkage behaviour}

\subsubsection{Bricks without additions}

Earth bricks of the cohesive soil with neither reinforcement fibres nor cement or gypsum has the maximum shrinkage and shows extensive 
crack formation. Figure 4 shows the pattern of cracks under the curing temperature, which gives rise to entirely disintegrated specimens.

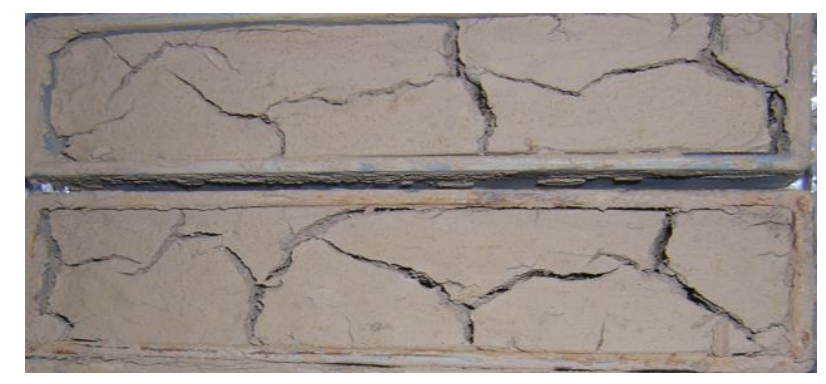

Fig. (4): Shrinkage and crack formation for earth bricks.

\subsubsection{The influence of fibre contents}

The average shrinkage percentage of unfired earth bricks reinforced with wheat straw are 4.161, 2.615 and $0.573 \%$ for the fibres contents of $0 \%$, $1 \%$ and $3 \%$ respectively, while the shrinkage percentages for bricks reinforced with barley straw fibres are $4.161,3.458$ and $0.613 \%$ for reinforcement fibres contents of $0 \%, 1 \%$ and $3 \%$ respectively. The mentioned results illustrated that increasing wheat straw fibre percentages from $0 \%$ to $1 \%$ caused a decrease of shrinkage percentages to $37.15 \%$ in comparison to bricks without reinforcement fibres. On the other hand, increasing wheat straw fibre percentages from $0 \%$ to $3 \%$ caused a decrease of shrinkage percentages to $86.23 \%$. Also, the results illustrated that, increasing barley fibre percentages from $0 \%$ to $1 \%$ caused a decrease of shrinkage percentages to $16.89 \%$ in comparison to bricks without reinforcement fibres. While, increasing barley straw percentages from $0 \%$ to $3 \%$ caused a decrease of shrinkage percentages to $82.27 \%$. The change in shrinkage by altering the fibre content is shown in Fig.5. As expected, shrinkage percent decreased with an increase in fibre content. Figure 5 also shows that the decrease in shrinkage was gradual with increasing fibre content. The results showed significance difference between bricks reinforced with wheat and barley straw fibres and bricks without fibres ( $\mathrm{P}$ $<0.05)$. 


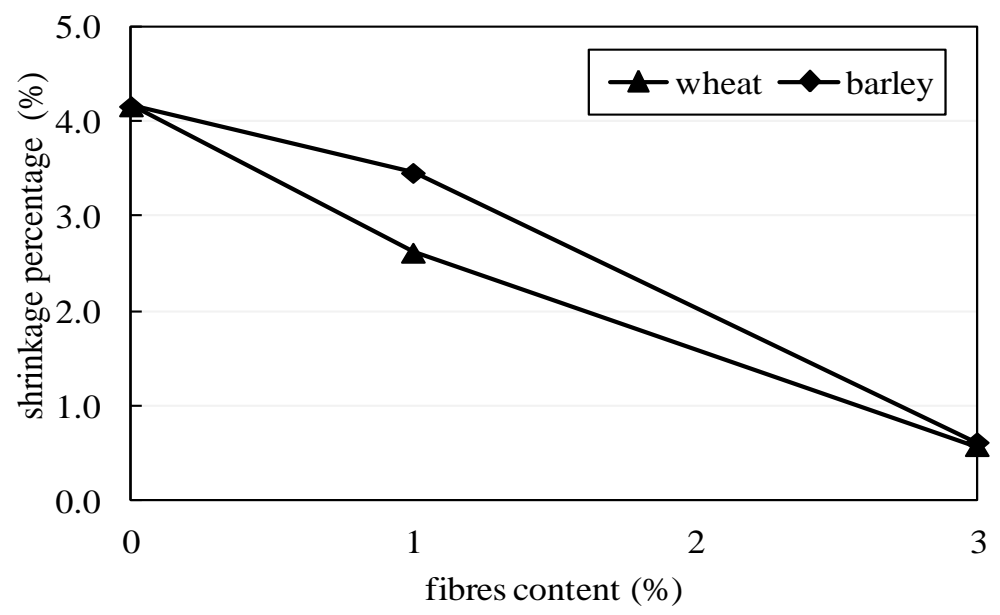

Fig. (5): The influence of reinforcement fibres.

\subsubsection{The influence of cement content}

\subsubsection{Cement content with $1 \%$ fibre}

Figure 6a shows the relationship between cement content and shrinkage percentages for bricks reinforced with $1 \%$ fibre. The figure shows that shrinkage increases slightly with increasing cement content. The results showed no significance difference between the performance of wheat and barley straw fibre reinforced bricks $(\mathrm{P}>0.05)$. The average shrinkage percentages of wheat straw reinforced earth bricks are 2.615, 2.731 and $2.93 \%$ for cement contents of $0 \%, 5 \%$ and $10 \%$ respectively. The percentages of shrinkage for bricks reinforced with barley straw fibres are $3.458,3.51$ and $3.60 \%$ for cement contents of $0 \%, 5 \%$ and $10 \%$ respectively. The results showed also that increasing cement content from $0 \%$ to $5 \%$ caused an increase of shrinkage percentages to $4.44 \%$ for wheat straw in comparison to bricks without reinforcement fibres. On the other hand, increasing wheat straw fibre percentages from $0 \%$ to $10 \%$ caused an increase of shrinkage percentages to $12.05 \%$.

Also, the results of bricks reinforced by barley straw fibres illustrated that, increasing cement content from $0 \%$ to $5 \%$ caused an increase of shrinkage percentages to $1.50 \%$. This means that, increasing cement percentages from $0 \%$ to $10 \%$ caused an increase of shrinkage percentages to $4.11 \%$. The figure also showed that the shrinkage percentages for barley straw fibre reinforced bricks is higher than wheat straw reinforced bricks. 


\subsubsection{Cement content with $3 \%$ fibre}

The average shrinkage of bricks reinforced with wheat straw fibres are $0.573,0.601$ and $0.653 \%$ for the cement contents of $0 \%, 5 \%$ and $10 \%$ respectively. The shrinkage percentages of barley straw reinforced bricks are $0.613,0.710$ and $0.82 \%$ for cement contents of $0 \%, 5 \%$ and $10 \%$ respectively. Figure $6 \mathrm{~b}$ shows the relationship between bricks cement content and shrinkage percentages with $3 \%$ fibre. The figure showed that shrinkage slightly increased with increasing cement content. The results showed no significance difference between wheat and barley reinforced bricks $(\mathrm{P}>0.05)$.

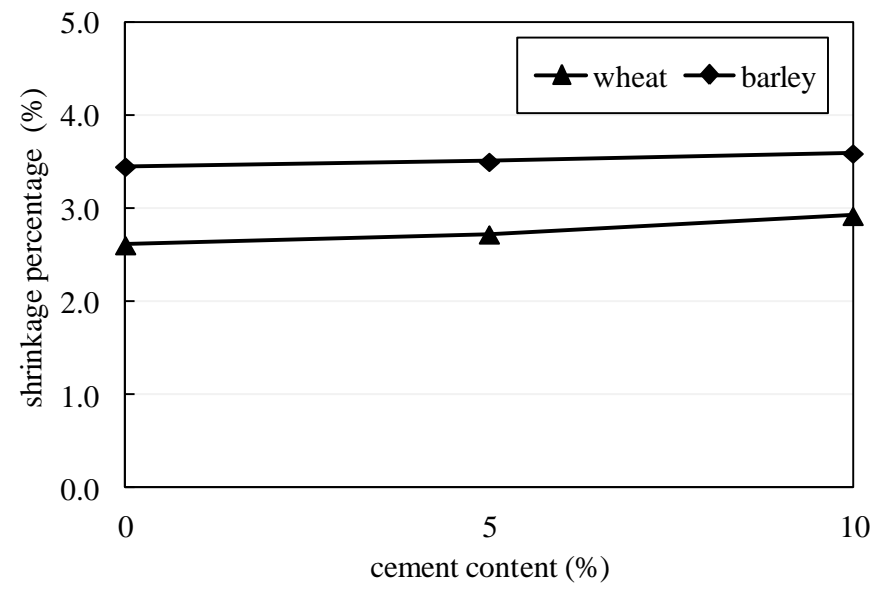

a)

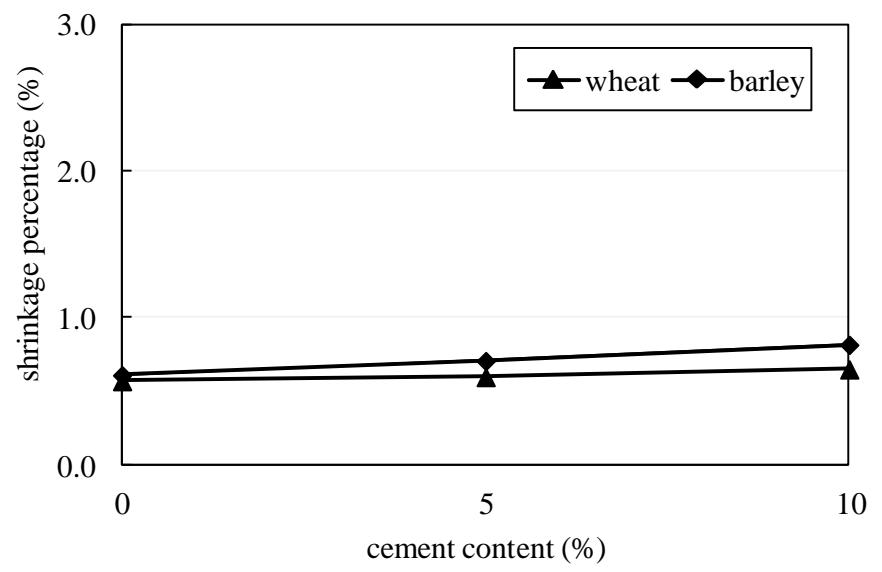

b)

Fig. (6): The influence of cement content, a) 1\% fibres, b) $3 \%$ fibres. 
It could be noticed that, the results for wheat straw fibres showed that increasing cement content from $0 \%$ to $5 \%$ caused an increase of shrinkage percentages to $4.89 \%$. While, increasing cement from $0 \%$ to $10 \%$ caused an increase of shrinkage percentages to $13.96 \%$. Also for bricks reinforced by barley straw fibres, the results illustrated that, increasing cement content from $0 \%$ to $5 \%$ caused an increase of shrinkage percentages to $15.82 \%$. While, increasing cement from $0 \%$ to $10 \%$ caused a decrease of shrinkage percentages to $33.77 \%$. The figure also showed that the shrinkage percentages for barley straw fibre reinforced bricks is higher than wheat straw reinforced bricks.

\subsubsection{The influence of gypsum content}

\subsubsection{Gypsum content at $1 \%$ fibre}

Figure 7a shows the relationship between bricks gypsum content and shrinkage percentages reinforced with $1 \%$ and $3 \%$ fibre. The figure shows that shrinkage increases slightly with increasing gypsum content. The results showed no significance difference between the performance of wheat and barley straw fibre reinforced bricks $(\mathrm{P}>0.05)$. The average shrinkage percentages of unfired wheat straw reinforced earth bricks are $2.615,3.542$ and $3.614 \%$ for gypsum contents of $0 \%, 5 \%$ and $10 \%$ respectively. The percentages of shrinkage for bricks reinforced with barley straw fibres are 3.458, 3.677 and $3.829 \%$ for gypsum contents of $0 \%, 5 \%$ and $10 \%$ respectively.

It could be seen that, obtained results for wheat straw fibres showed that increasing gypsum content from $0 \%$ to $5 \%$ caused an increase of shrinkage percentages to $35.45 \%$ in comparison to bricks without gypsum. While, increasing gypsum content from $0 \%$ to $10 \%$ caused an increase of shrinkage percentages to $38.20 \%$.

Similarly, for barley straw, the results illustrated that, increasing gypsum content from $0 \%$ to $5 \%$ caused an increase of shrinkage percentages to $6.33 \%$ comparing to bricks without gypsum. While, increasing gypsum from $0 \%$ to $10 \%$ caused an increase of shrinkage percentages to $10.73 \%$. The figure also showed that the shrinkage percentages for barley straw fibre reinforced bricks is higher than wheat straw reinforced bricks.

\subsubsection{Gypsum content with $3 \%$ fibre}

The average shrinkage of bricks reinforced with wheat straw fibres are $0.573,0.702$ and $0.850 \%$ for the gypsum contents of $0 \%, 5 \%$ and $10 \%$ 
respectively. The shrinkage percentages of barley straw reinforced bricks are $0.613,0.824$ and $1.021 \%$ for cement contents of $0 \%, 5 \%$ and $10 \%$ respectively. Figure $7 \mathrm{~b}$ shows the relationship between brick cement content and shrinkage percentages with $3 \%$ fibre. The figure showed that shrinkage slightly increased with increasing cement content. The results showed no significance difference between wheat and barley reinforced bricks $(\mathrm{P}>0.05)$. The present results revealed that bricks reinforced with wheat straw fibres showed that rising gypsum percentages from $0 \%$ to $5 \%$ caused an increase of shrinkage percentages to $22.51 \%$ in comparison to bricks with no gypsum. Alternatively, the shrinkage percentages were elevated to $48.34 \%$ by increasing gypsum from $0 \%$ to $10 \%$.

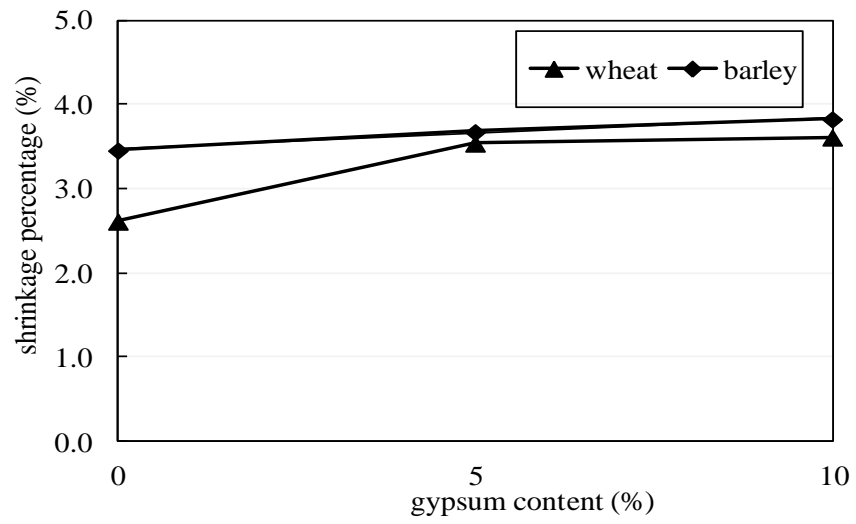

a)

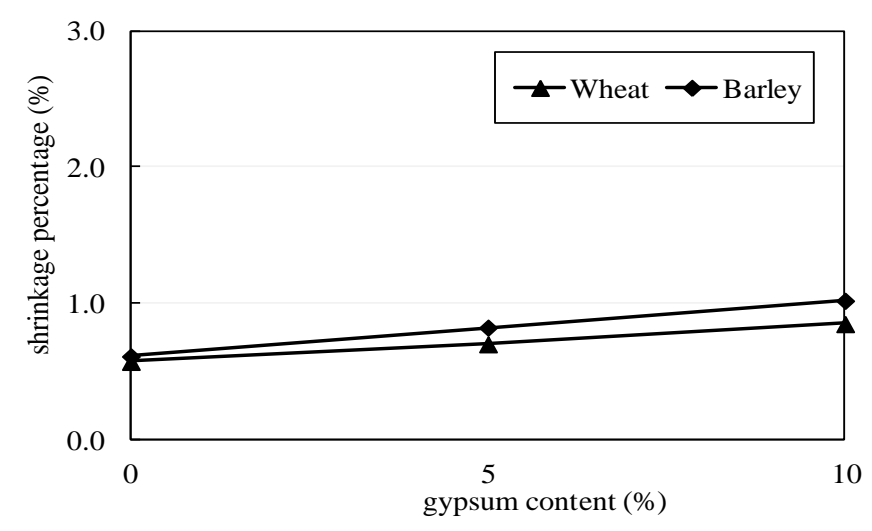

b)

Fig. (7): The influence of gypsum content, a) 1\% fibres, b) $3 \%$ fibres.

For bricks reinforced by barley straw fibres, the results illustrated that, increasing gypsum content from $0 \%$ to $5 \%$ caused an increase of 
shrinkage percentages to $34.42 \%$ in similar to bricks with no gypsum content. While, increasing gypsum percentages from $0 \%$ to $10 \%$ caused increasing the shrinkage percentages to $66.56 \%$. The figure also showed that the shrinkage percentages for barley straw fibre reinforced bricks stabilised gypsum is higher than wheat straw reinforced bricks.

A comparison of the earth bricks in Sections 3.1, 3.2 and 3.3 shows that the earth bricks of cohesive soil with neither reinforcement fibres nor cement or gypsum has the maximum shrinkage and shows extensive crack formation. Fibre properties, i.e. components, surface roughness and surface polarity have important contribution to fibre wettability and adhesion in composites. However surface chemistry of the fibres has influence on the mechanical properties of the composites (Bledzki et al., 2010).

\subsection{Multiple regression analysis}

Regression analysis generates an equation to describe the relationship between shrinkage of different brick materials and one or more variables such as cohesive soil, fibres content, cement content and gypsum content. The optimum equation for shrinkage percentage for all types of blocks is linear equation. The following equation was obtained:

$$
y=a+b x
$$

Where,

y : shrinkage percentage (\%)

$\mathrm{x} \quad$ : fibre or cement content or gypsum content

a,b : Constants are listed in Table (2)

Regression coefficients represent the mean change in the response variable for one unit of change in the predictor variable. Table (2) show the constants of shrinkage percentage equation for different brick materials. The results presented in table (2) illustrated that the slopes of the equation are -1.171 and -1.217 for wheat and barley respectively. This means that increasing the fibres content lead to decrease the shrinkage percentage for both wheat and barley straw fibres. While the slopes for cement at $1 \%$ and $3 \%$ fibres were 0.032 and 0.021 respectively. On the other hand, the slopes for gypsum at $1 \%$ and $3 \%$ fibres were 0.099 and 0.028 respectively . These findings confirmed that increasing cement or 
gypsum contents resulting in increasing the shrinkage percentages for different earth bricks.

Finally, to limit shrinkage, if it is excessive for our building needs, we can increase the amount of larger and inert soil particles such as fibres and cement or gypsum. The particles are massive in comparison to the soil particles, and do not swell and shrink with drying. So, if we get enough of fibres in a soil mix we can limit shrinkage. Fibres interrupt cracks if they should develop and prevent them from growing larger and cracking the material.

\begin{tabular}{ccccccc}
\hline \hline \multirow{2}{*}{$\begin{array}{c}\text { brick } \\
\text { materials }\end{array}$} & \multicolumn{3}{c}{ wheat straw } & \multicolumn{3}{c}{ barley straw } \\
\cline { 2 - 3 } \cline { 5 - 6 } & $\mathrm{a}$ & $\mathrm{B}$ & $\mathbf{R}^{\mathbf{2}}$ & \multicolumn{2}{c}{ constants } & \multirow{2}{*}{$\mathbf{R}^{\mathbf{2}}$} \\
\hline \hline \begin{tabular}{c} 
Fibres \\
\cline { 2 - 3 } Cement
\end{tabular} & 4.011 & -1.171 & $\mathbf{0 . 9 8 7}$ & 4.367 & -1.217 & $\mathbf{0 . 9 7 9}$ \\
$\begin{array}{c}\text { (1\% fibres) } \\
\text { cement }\end{array}$ & 2.601 & 0.032 & $\mathbf{0 . 9 7 7}$ & 3.452 & 0.014 & $\mathbf{0 . 9 7 7}$ \\
$\begin{array}{c}\text { (3\% fibres) } \\
\text { Gypsum }\end{array}$ & 0.612 & 0.021 & $\mathbf{0 . 9 9 8}$ & 0.569 & 0.008 & $\mathbf{0 . 9 7 1}$ \\
$\begin{array}{c}1 \% \text { fibres }) \\
\text { gypsum }\end{array}$ & 2.758 & 0.099 & $\mathbf{0 . 8 0 4}$ & 3.469 & 0.037 & $\mathbf{0 . 9 8 9}$ \\
$(3 \%$ fibres $)$ & 0.569 & 0.028 & $\mathbf{0 . 9 9 8}$ & 0.615 & 0.041 & $\mathbf{0 . 9 9 9}$ \\
\hline \hline
\end{tabular}

Table2: Equation constants and coefficient of determination of the relationship between shrinkage and fibres, cement and gypsum.

\section{CONCLUSIONS}

Our testing results show that the shrinkage of earth brick is influenced by several factors, e.g cohesive soil, fibre content and type, cement and gypsum. The earth brick without reinforcement fibre shows extensive crack formation, which leads to disintegration of the specimens. Both the reinforcement fibres, cement and gypsum have some positive 
effect on shrinkage. However, reinforcement fiber has greater effect on shrinkage than cement and gypsum. The crack formation decreases with increasing fibre content and increases with increasing cohesive soil. The average shrinkage percentage of unfired earth bricks reinforced with wheat straw are 4.161, 2.615 and $0.573 \%$ for the fibres contents of $0 \%$, $1 \%$ and $3 \%$ respectively, while the shrinkage percentages for bricks reinforced with barley straw fibres are $4.161,3.458$ and $0.613 \%$ for reinforcement fibres contents of $0 \%, 1 \%$ and $3 \%$ respectively. The percentages of shrinkage for bricks reinforced with barley straw fibres are $3.458,3.51$ and $3.60 \%$ for cement contents of $0 \%, 5 \%$ and $10 \%$ respectively. additionally, the percentages of shrinkage for bricks reinforced with barley straw fibres are 3.458, 3.677 and $3.829 \%$ for gypsum contents of $0 \%, 5 \%$ and $10 \%$ respectively.

In general, higher fibre content are to be preferred to improve the performance of earth bricks, i.e. to reduce shrinkage and crack formation.

\section{REFERENCES}

AIA, (2003) American Institute of Architects (AIA). Value engineering's history in construction, 2006.

Al-Amoudi O.S., T.O. Abiola T.O. and Maslehuddin M. (2006) Effect of superplasticizer on plastic shrinkage of plain and silica fume cement concretes. Construction and Building materials, 20(9):642647.

Ashour T., Georg H. and Wu W. (2011) Performance of straw bale wall: A case of study. Energy and Buildings, 43: 1960-1967.

Ashour T., Heiko, G., Wu W. (2011) An experimental investigation on equilibrium moisture content of earth plaster with natural reinforcement fibres for straw bale buildings. Journal of Thermal Engineering, 31:293-303.

Ashour T., $\boldsymbol{W u}$ W. (2010) An experimental study on shrinkage of earth plaster with natural fibres for straw bale buildings. International Journal of Sustainable Engineering, 3(4): 299-304 . 
Ashour T., Wu W. (2010) The influence of natural reinforcement fibres on erosion properties of earth plaster materials for straw bale buildings. Journal of Building Appraisal, 5(4):329-340.

Ashour, T., Wieland, H., Georg, H., Bockisch, F-J. and Wu, W. (2010) The Influence of Natural Reinforcement Fibres on Insulation Values of Earth Plaster for Straw Bale Buildings, Materials and Design, 31:4676-4685.

ASTM D4943 (1995) Standard Test Method for Shrinkage Factors of Soils by the Wax Method.

Bai, Y., F. Darcy F. and Basheer P.M. (2005) Strength and drying shrinkage properties of concrete containing furnace bottom ash as fine aggregate. Construction and Building materials, 19(9):691-697.

Bledzki A.K. and Jaszkiewicz A. (2012) Mechanical performance of biocomposites based on PLA and PHBV reinforced with natural fibres- A comparative study to PP, Composites Science and Technology, 70: 1687-1696.

Bledzki A.K., Mamun A.A. and Volk J. (2010) Barley husk and coconut shell reinforced polypropylene composites: The effect of fibre physical, Chemical and Surface properties, 70:840-746.

Bouhicha M., Aouissi F. and Kenai, S. (2005) Performance of composite soil reinforced with barley straw. Journal of Cement and Concrete Composites, 27: 617-621.

Campbell M.D. and Coutts R.S.P. (1980) Wood fibre-reinforced cement composites. Journal of Materials Science, pp. 1962-1970.

Demir I. (2006) An investigation on the production of construction brick with processed waste tea. Building and Environment, 41: 12741278 .

Duke J.A. Atchly A.A. (1984) Proximate analysis. In Chiste BR, editor. The handbook of plant science in agriculture. CRC Press, Inc.: Boca Raton, FL. 
Hossain K.M.A., Lachemi M. and Esa S. (2007) Stabilized soils for construction applications incorporating natural resources of Papua new Guinea, Journal of Resources Conversation \& Recycling, 51: 711-731.

Joshi S.V., Drzal L. T., Mohanty A.K. and Arora S. (2004) Are natural fibres composites environmentally superior to glass fibres reinforced composites?, Composites: Part A, 35: 371-376.

Li, Z., Wang X. and Wang L. (2006) Properties of hemp reinforced concrete composites. Composites: Part A, 37: 497-505.

Montes-H G. (2005) Swelling-shrinkage measurements of bentonite using coupled environmental scanning electron microscopy and digital image analysis. Journal of Colloid and Interface Science, 284: 271-277.

Mwaikambo L. Y. and Ansell M.P. (2003) Hemp fibres reinforced cashew nut shell liquid composites. Composites science and Technology, 63:1297-1305.

Yetgin S., Cavdar O. and Cavda A. (2006) The effects of the fibre contents on the mechanic properties of the adobes. Journal of Construction and Building Materials, 22 (3), 222-227.

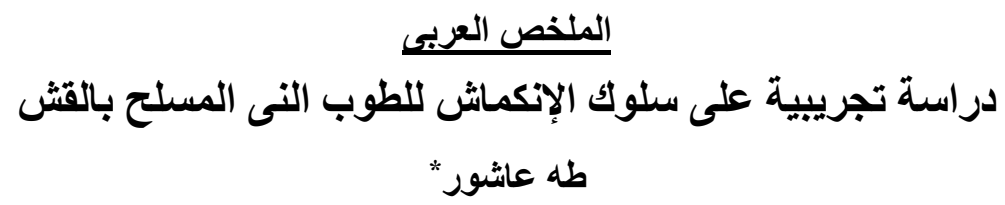

تتجه أبحاث مو اد البناء إلى المو اد الطبيعية لما لها من خصائص طبيعية وحر ارية ممتازة تؤدى الئى

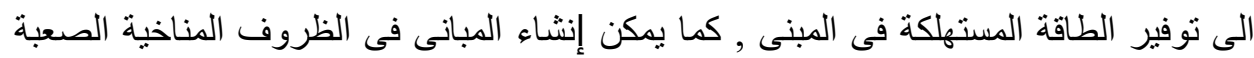

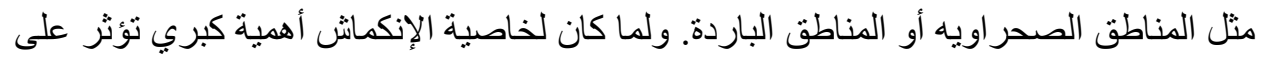

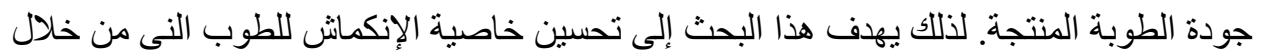
تسليحة بالقش, وكذلك إضاف الجبس والأسمنت بنسب خلط مختلفة . ولذلك فى هذا البحث نم

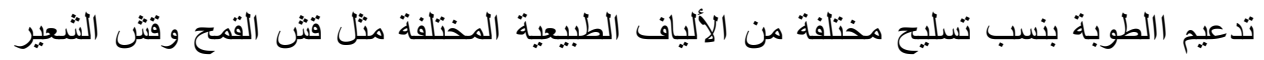

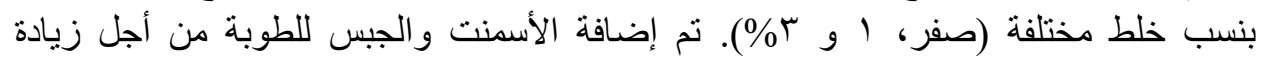
الصلادة و المتانة وبنسب مختلفة (صفر ، م و و • ( \%).

* أستاذ مساعدـ قسم الهندسة الزراعية_ كلية الزراعة بمشتهر - جامعة بنها- مصر 
تم حساب نسب الخلط كنسبة وزنية من وزن التربة, وكانت جميع النسب السابقة كلها منسوبة

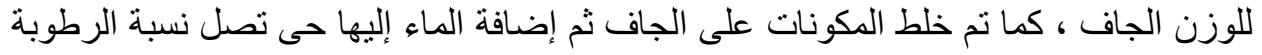

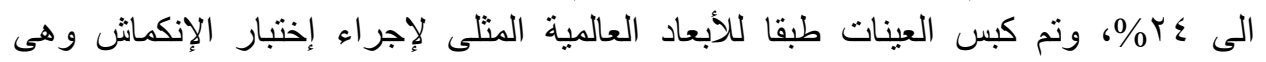

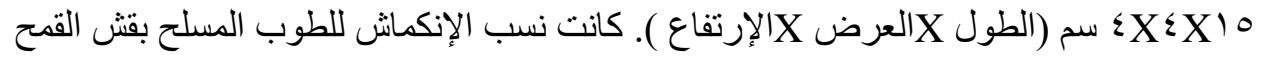

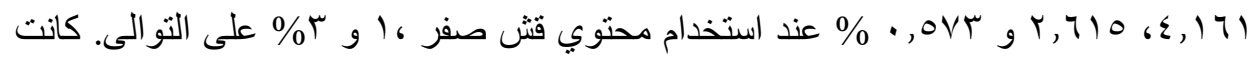

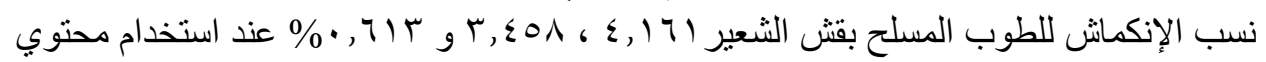

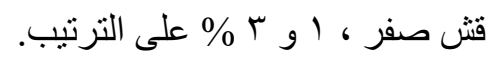

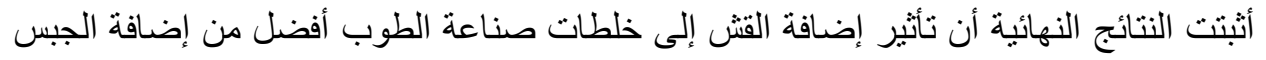

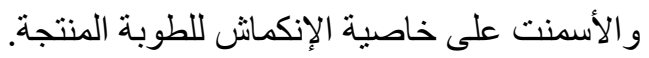
الكلمات الدالة:الطوب اللبن- الإنكماش- قش الأكماث القمح- قش الثعير - الأسمنت ـ الجبس. 